\title{
Effects of nitrogen fertilization on diazotrophic activity of microorganisms associated with Sphagnum magellanicum
}

\author{
Martine A. R. Kox • Claudia Lüke • Christian Fritz • Eva van den Elzen • Theo van Alen • \\ Huub J. M. Op den Camp • Leon P. M. Lamers • Mike S. M. Jetten • Katharina F. Ettwig
}

Received: 9 April 2015 / Accepted: 2 March 2016 / Published online: 29 March 2016

(C) The Author(s) 2016. This article is published with open access at Springerlink.com

\begin{abstract}
Background and aims In pristine ombrotrophic Sphagnum-dominated peatland ecosystems nitrogen $(\mathrm{N})$ is often a limiting nutrient, which is replenished by biological $\mathrm{N}_{2}$ fixation and atmospheric $\mathrm{N}$ deposition. It is, however, unclear which impact long-term $\mathrm{N}$ deposition has on microbial $\mathrm{N}_{2}$ fixing activity and diazotrophic diversity, and whether phosphorus (P) modulates the response. Therefore, we studied the impact of increased $\mathrm{N}$ deposition and $\mathrm{N}$ depletion on microbial $\mathrm{N}_{2}$ fixation and diazotrophic diversity associated with the peat moss
\end{abstract}

Responsible Editor: Hans Lambers.

Electronic supplementary material The online version of this article (doi:10.1007/s11104-016-2851-z) contains supplementary material, which is available to authorized users.

M. A. R. Kox $(\bowtie) \cdot$ C. Lüke $\cdot$ T. van Alen

H. J. M. Op den Camp • M. S. M. Jetten · K. F. Ettwig

Department of Microbiology, Radboud University, Nijmegen,

Netherlands

e-mail:m.kox@science.ru.nl

C. Fritz $\cdot$ E. van den Elzen · L. P. M. Lamers

Aquatic Ecology and Environmental Biology, Radboud

University, Nijmegen, Netherlands

C. Fritz

Experimental Plant Ecology, Institute of Water \& Wetland

Research, Heyendaalseweg 135, 6525 AJ Nijmegen,

The Netherlands

C. Fritz

Sustainable Agriculture, Rhein-Waal University for Applied

Science, Wiesenstraße 5, 47575 Kleve, Germany
Sphagnum magellanicum, and their interaction with $\mathrm{P}$ availability.

Methods Nitrogenase activities of S. magellanicumassociated microorganisms were determined by acetylene reduction assays (ARA) and ${ }^{15} \mathrm{~N}_{2}$ tracer methods on mosses from two geographically distinct locations with different $\mathrm{N}$ deposition histories, high or low $\mathrm{N}$ deposition, and in samples depleted in $\mathrm{N}$ (grown 3 years in the greenhouse) versus recent field samples. The short-term response to increased $\mathrm{N}$ deposition was tested for mosses differing in $\mathrm{N}$ and $\mathrm{P}$ fertilization histories. In addition, diversity of diazotrophic microorganisms was assessed by nifH gene amplicon sequencing of $\mathrm{N}$-depleted mosses.

Results We showed distinct and persistent differences in diazotrophic communities and their activities associated with $S$. magellanicum from sites with high versus low $\mathrm{N}$ deposition. Initially, diazotrophic activity was six times higher for the low N site. During incubation and repeated ARA, however, this activity strongly decreased, while it remained stable for the high $\mathrm{N}$ site. Activity for the high $\mathrm{N}$ site could not be increased by long-term experimental $\mathrm{N}$ deprivation. Short-term, experimental $\mathrm{N}$ application had an inhibitory effect on $\mathrm{N}_{2}$ fixation for both sites, which was not observed in mosses with high indirect $P$ availability.

Conclusions We conclude that although $\mathrm{N}$ deposition negatively affects $\mathrm{N}_{2}$ fixation as also shown in previous studies, long-term effects of $\mathrm{N}$ deprivation on the diazotrophic activity and community are more complex. Furthermore, our results indicated that $\mathrm{P}$ availability might be an important factor in modulating the response of Sphagnum-associated diazotrophs to $\mathrm{N}$ deposition. 
Keywords Peatland · Nitrogen fixation · Diazotroph diversity Phosphorus $\cdot{ }^{15} \mathrm{~N}_{2}$. Acetylene reduction. nifH $\cdot$ Nitrogen deposition

\section{Introduction}

Although nitrogen $(\mathrm{N})$ in the form of dinitrogen gas $\left(\mathrm{N}_{2}\right)$ is the most abundant element in the Earth's atmosphere, low availability of this essential element for plants is often limiting primary production in pristine ecosystems (Canfield et al. 2010). The rates of atmospheric $\mathrm{N}$ deposition have increased at record pace over the last decades in many regions of the world, due to industrialization, increased traffic and the intensive use of $\mathrm{N}$-fertilizers and manure in agriculture (Gruber and Galloway 2008). Nowadays, biological $\mathrm{N}_{2}$ fixation is estimated to contribute about $200-250 \mathrm{Tg} \mathrm{N}$ year $^{-1}$ $\left(\mathrm{Tg}=10^{12} \mathrm{~g}\right)$ to the biosphere, including $\mathrm{N}_{2}$ fixation associated with agricultural crops (Gruber and Galloway 2008; Fowler et al. 2013), while anthropogenic input from fertilizers and increased atmospheric deposition of reactive nitrogen $\left(\mathrm{NH}_{\mathrm{x}}, \mathrm{NO}_{\mathrm{y}}\right)$ nearly matches this value (up to $195 \mathrm{Tg} \mathrm{N}$ year ${ }^{-1}$; Gruber and Galloway 2008). This has massively disturbed the $\mathrm{N}$ balance in many (pristine) ecosystems, and is expected to possibly change even $\mathrm{N}$-limited sites to sites with excess N availability (Bobbink et al. 1998; Granath et al. 2014).

The effects of high $\mathrm{N}$ deposition are most severe in nutrient-poor ecosystems such as Sphagnum-dominated peatlands, which are very sensitive to increased nutrient influx (Lamers et al. 2000; Tomassen et al. 2004; Verhoeven et al. 2011; Novak et al. 2015). Here, additional $\mathrm{N}$ supply might lead to higher biomass production and therefore carbon sequestration, but an opposite or mixed effect can also be envisaged: $\mathrm{N}$ in the form of nitrate/nitrite could serve as electron acceptor for peat degradation, and increase degradability of otherwise very recalcitrant peat bog biomass (via an "improved" $\mathrm{C}: \mathrm{N}$ stoichiometry and/or induced shifts from Sphagnum to vascular plants (Bragazza et al. 2012)), with greenhouse gases carbon dioxide $\left(\mathrm{CO}_{2}\right)$ and methane $\left(\mathrm{CH}_{4}\right)$ being the products of this oxygen-limited degradation. Since peatlands are estimated to store one-third of all terrestrial carbon (Gorham 1991), it is crucial to understand these feedback effects of increased N supply (Granath et al. 2014).
Many studies in peatlands have focused on the effects of high $\mathrm{N}$ deposition (i.e. $>10 \mathrm{~kg} \mathrm{~N}^{-1}$ year $^{-1}$; Lamers et al. 2000) on plants, since plants are assumed to be the main consumers of $\mathrm{NH}_{4}{ }^{+}$and $\mathrm{NO}_{3}{ }^{-}$in terrestrial ecosystems. Sphagnum mosses have been shown to be very efficient in retaining nitrogenous compounds from $\mathrm{N}$ deposition, preferentially taking up $\mathrm{N}$ in the form of $\mathrm{NH}_{4}{ }^{+}$(Fritz et al. 2014). The effects of high $\mathrm{N}$ deposition on Sphagnum moss productivity are dependent on the level, where at low deposition levels, up to about $10 \mathrm{~kg} \mathrm{~N} \mathrm{ha}^{-1}$ year $^{-1}$, mosses might still benefit from the additional $\mathrm{N}$ input (Lamers et al. 2000; Berg et al. 2012). At deposition levels higher than $18 \mathrm{~kg} \mathrm{~N} \mathrm{ha}^{-1}$ year $^{-1}$, Sphagnum spp. become saturated with $\mathrm{N}$ and excess $\mathrm{N}$ leaches deeper into the system, which facilitates growth of vascular plants, changes nitrogen cycling and decomposition rates, and may result in degradation of peatlands (Lamers et al. 2000; Bragazza 2006; Wu and Blodau 2013; Novak et al. 2015). Moreover, high N availability in the form of $\mathrm{NH}_{4}^{+}$ultimately could become toxic to wetland plants, especially under P-limited conditions (Lamers et al. 2012). Yet, when phosphorus (P) availability is increased simultaneously, it is thought that the negative physiological effects that plants experience under high $\mathrm{N}$ loads can be alleviated, due to stimulation of primary production (Lamers et al. 2012; Fritz et al. 2012), and that also their microbial community might benefit directly from non-limiting P-supply.

Sphagnum mosses and their microbial associates have been demonstrated to be specific throughout the moss's life cycle, with a higher microbial diversity observed in Sphagnum species from more eutrophic habitats (Opelt et al. 2007; Bragina et al. 2011, 2014). The mosses consume carbon dioxide $\left(\mathrm{CO}_{2}\right)$ produced during decomposition in lower peat layers, while epi- and endophytic microorganisms of Sphagnum contribute additional $\mathrm{CO}_{2}$ by converting methane $\left(\mathrm{CH}_{4}\right)$ to $\mathrm{CO}_{2}$ (Raghoebarsing et al. 2005; Kip et al. 2011). Microbial analyses of peat mosses demonstrated the presence of a wide variety of diazotrophs, which might serve as nutrient suppliers to the moss (Andersen et al. 2012; Berg et al. 2012; Bragina et al. 2014). Nitrogen is an important nutrient limiting or co-limiting primary production in boreal peatlands. The only known biological process that is able to convert $\mathrm{N}_{2}$ into a reactive form of $\mathrm{N}$ replenishing the ecosystems' $\mathrm{N}$-pool is $\mathrm{N}_{2}$ fixation, which is known to be performed by a large variety of prokaryotes called diazotrophs (Robertson and Vitousek 2009). In peatlands, diazotrophic activity ( $\mathrm{N}_{2}$ fixation) 
has been shown to account for up to $35 \%$ of the $\mathrm{N}$ assimilated by Sphagnum species (Berg et al. 2012; Larmola et al. 2014). Biological $\mathrm{N}_{2}$ fixation is catalyzed by the enzyme nitrogenase, consisting of an $\alpha_{2} \beta_{2}$ heterotetramer (NifD and NifK respectively) and a homodimer dinitrogen reductase $\gamma_{2}$ (NifH; Rees et al. 2005). The nifH gene encoding for the NifH homodimer is most widely used as biomarker to study the diversity of diazotrophs (Gaby and Buckley 2012; Levy-Booth et al. 2014).

Moreover, diazotrophy has been suggested to be an important process in the accumulation of $\mathrm{N}$ during succession of peatlands (Larmola et al. 2014), where methanotrophic diazotrophs rather than cyanobacteria may account for a significant part of the $\mathrm{N}_{2}$ fixation activity. In a Canadian ombrotrophic bog, investigation of the active diazotrophic community showed higher relative abundance of nifH transcripts originating from methanotrophs than those from cyanobacteria (Vile et al. 2014). Nevertheless, many questions on the relative importance of different diazotrophic microorganisms in peat mosses remain and in contrast to plant communities, the effect of $\mathrm{N}$ deposition on microbial assemblages in peatlands has been less well explored (Bodelier 2011; Andersen et al. 2012; Ho and Bodelier 2015).

The expression of the nitrogenase enzyme is down regulated by ammonium availability. Also it is known that high concentrations of nitrate might result in formation of nitrite, which irreversibly inactivates the nitrogenase enzyme (Postgate 1982). Multiple studies have shown that $\mathrm{N}$ deposition affects diazotrophic activity in a dose-dependent way. Recently, Rousk et al. (2013b) showed that $\mathrm{N}_{2}$ fixation rates in the forest moss Pleurozium schreberi, mainly colonized by cyanobacteria, were not sensitive to $\mathrm{N}$ amendments up to $10 \mathrm{~kg} \mathrm{~N}^{-1}$ year $^{-1}$. This result was similar to the upper limit of $\mathrm{N}$ deposition that Sphagnum mosses could adsorb before $\mathrm{N}$ compounds started to leach into deeper peat layers, as calculated in Lamers et al. (2000). However, when the Pleurozium mosses were experimentally deprived of $\mathrm{N}$, after having been exposed to high $\mathrm{N}$ deposition rates, their microbial community reacted with an increase in $\mathrm{N}_{2}$ fixation rates (Rousk et al. 2013b). Similarly, along a natural gradient of N deposition levels, the diazotrophic activity (mainly of cyanobacteria) associated with the forest mosses Hylocomium splendens and P. schreberi was shown to decrease with increasing $\mathrm{N}$ deposition levels (Leppänen et al. 2013). Studies on the effect of $\mathrm{N}$ fertilization on S. fuscum and $S$. angustifolium-associated diazotrophs in a pristine peat bog showed that the diazotrophic activity was negatively affected by high $\mathrm{N}$ input, although moss productivity did not change (Vile et al. 2014). The difference in response pattern to $\mathrm{N}$ deposition between the study of Rousk et al. (2013b) and the others indicates that increased $\mathrm{N}$ deposition may not have a uniform effect on diazotrophs in all moss species. Rather, it suggests that the response may be influenced by diazotrophic community composition, as well as by differential plant-microbe interactions.

For the globally occurring peat moss species Sphagnum magellanicum, N deposition effects with respect to its microbial diazotrophic community have not been studied yet. Because of its abundance in ombrotrophic and oligotrophic sites from boreal to temperate regions (Laine et al. 2009), it is an attractive species to study the effects of habitat difference. The main question in this study was whether S. magellanicum-associated $\mathrm{N}_{2}$ fixation was affected by high $\mathrm{N}$ deposition, and whether $\mathrm{P}$ availability modulated this effect. We compared, for the first time, the same moss species (S. magellanicum) from a pristine versus an $\mathrm{N}$-loaded site to study whether $\mathrm{N}$ limitation stimulates $\mathrm{N}_{2}$ fixation. Along this line, long-term effects of $\mathrm{N}$ deposition and of $\mathrm{N}$ deposition history on $\mathrm{N}_{2}$ fixation in Sphagnum mosses had not been studied before. Like in forest mosses, we expected (1) Sphagnum associated $\mathrm{N}_{2}$ fixation rates to decrease upon $\mathrm{N}$ fertilization, since $\mathrm{N}$ will than be taken up directly from the environment rather than costly being produced via $\mathrm{N}_{2}$ fixation. Secondly, it was expected (2) that $\mathrm{N}_{2}$ fixation rates increase upon $\mathrm{N}$ deprivation. Next, $\mathrm{P}$ is known to be a directly limiting factor for diazotrophy and often becomes the limiting factor for primary production with excess $\mathrm{N}$ input (Vitousek et al. 2002), however, it is not known whether indirect $\mathrm{P}$ availability, in the form of high P-content in plant-tissue, has the same effect. Therefore, we hypothesized that (3) high indirect $\mathrm{P}$ availability to stimulate $\mathrm{N}_{2}$ fixation, and to alleviate the negative effects of $\mathrm{N}$ deposition (Smith and Bennett 1999; Fritz et al. 2012). We expected (4) $\mathrm{N}_{2}$ fixation to be induced by limited $\mathrm{N}$ availability, either by absolute $\mathrm{N}$ limitation or by relative $\mathrm{N}$ limitation, (i.e. relative to the $\mathrm{P}$ limitation that plants and microorganisms experience). It was expected (5) that high indirect $P$ availability would result in a higher $\mathrm{N}$ demand for both plants and microorganisms, ultimately stimulating $\mathrm{N}_{2}$ 
fixation. The role of $\mathrm{P}$ as potential stimulator (direct or indirect) of $\mathrm{N}_{2}$ fixation in Sphagnum mosses has not yet been experimentally tested.

Our hypotheses were investigated in two microcosm fertilization experiments. First, to test the effect of $\mathrm{N}$ deposition on Sphagnum associated $\mathrm{N}_{2}$ fixation activity, $\mathrm{N}$ fertilization was applied to $S$. magellanicum collected from field sites exposed to either low or high $\mathrm{N}$ deposition over a long time period. Similarly, S. magellanicum from these sites that had been deprived of $\mathrm{N}$ for 3 years, were tested in the same set up and their diazotrophic community of the $\mathrm{N}$-deprived mosses was compared. In a second experiment, it was investigated whether Sphagnum mosses with a high P content due to former $\mathrm{P}$ fertilization, could modulate the effect of $\mathrm{N}$ fertilization.

\section{Material and methods}

Sample collection

Sphagnum magellanicum samples were collected from two geographical locations: (1) a low $\mathrm{N}$ deposition site located in the Andorra valley mire, Tierra del Fuego, Argentina $\left(<0.5 \mathrm{~kg} \mathrm{~N} \mathrm{ha}^{-1}\right.$ year $^{-1}$, Fritz et al. 2012) and (2) a high $\mathrm{N}$ deposition site, the Dwingelderveld, Dwingeloo, The Netherlands $\left(>25 \mathrm{~kg} \mathrm{~N} \mathrm{ha}^{-1}\right.$ year $^{-1}$ for more than 30 years; Lamers et al. 2000; Patberg 2011; for details see Table 1). The pristine bog vegetation of the Tierra del Fuego site was dominated by S. magellanicum interspersed with few vascular plants (cover $<2 \%$ ) such as Empetrum rubrum, Nothofagus antarctica, Carex magellanica, Marsipospermum grandiflorum. The Dutch high N deposition site Dwingelderveld consisted of several patches of bog vegetation that differed in successional state, containing species such as S. magellanicum, S. fallax, S. squarrosum, Andromeda polifolia and Eriophorum vaginatum (Patberg 2011). Mosses from both sites were collected in February 2010 and February 2013.

Experimental design and maintenance

Mosses collected from both sites in 2010 were maintained in the greenhouse facilities at Radboud University until 2013 (in total 37.5 months until incubation period) and were experimentally deprived of $\mathrm{N}$ by watering with artificial rainwater without added N-compounds (see Table 2 time table and Table S1 for

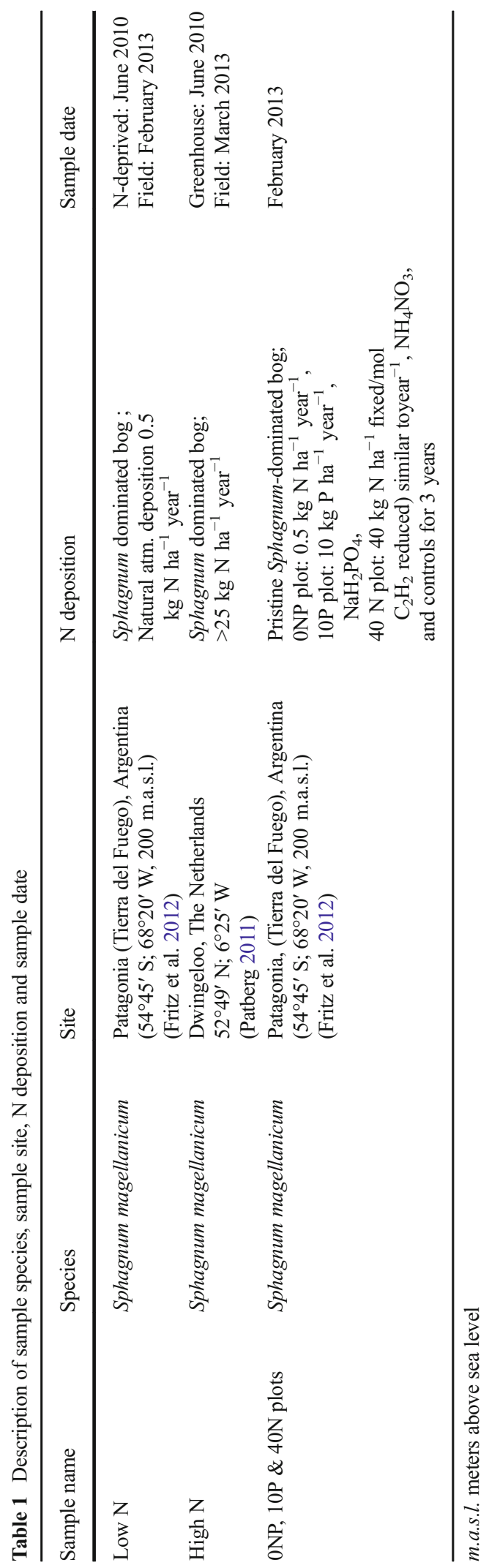


Table 2 Overview of fertilization measures and moss sampling in time, also see Table 1 for more info on sample locations

\begin{tabular}{|c|c|c|c|c|}
\hline 2008 & 2010 & \multicolumn{2}{|c|}{2013} & \multirow{6}{*}{ 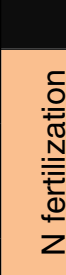 } \\
\hline Plots & ONP; 10P; 40P fertilization in field & ONP; 10P; 40P no fertilization in field & \multirow{5}{*}{ 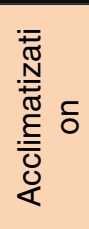 } & \\
\hline \multirow[t]{2}{*}{ Low $\mathrm{N}$ site } & Field & Field & & \\
\hline & Field & $\mathrm{N}$-deprivation in greenhouse & & \\
\hline \multirow[t]{2}{*}{ High $\mathrm{N}$ site } & Field & Field & & \\
\hline & Field & $\mathrm{N}$-deprivation in greenhouse & & \\
\hline & & & 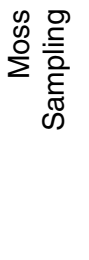 & 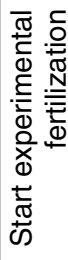 \\
\hline
\end{tabular}

rainwater recipe). Mosses collected in 2013 were collected from the field and together with the $\mathrm{N}$-deprived mosses from the greenhouse transferred to the climate rooms to acclimatize for 8 weeks prior to $\mathrm{N}$ fertilization experiments. From each site (high versus low $\mathrm{N}$ deposition) and treatment history (N-deprived or fresh from the field) 6 replicates were used in the experiments, except for mosses from the low $\mathrm{N}$ site collected in 2013, which had only 4 replicates due to limited sample size.

In a second experiment we tested whether $\mathrm{P}$ modulates $\mathrm{N}$ deposition effects on $\mathrm{N}_{2}$ fixation. From the Argentinean field site (low N deposition), S. magellanicum was collected from former experimental plots (Fritz et al. 2012). The plots had been treated from 2008 to 2010 with increased levels of either P (P; $10 \mathrm{~kg} \mathrm{P} h a^{-1}$ year ${ }^{-1}$, as $\mathrm{NaH}_{2} \mathrm{PO}_{4}$ dissolved in bog water) or nitrogen (N; $40 \mathrm{~kg} \mathrm{~N}^{-1}$ year $^{-1}$, as $\mathrm{NH}_{4} \mathrm{NO}_{3}$ dissolved in bog water; see Table 2 for timeline and Fritz et al. (2012) for further details). As a control, unfertilized mosses from the same site were collected at the same time. Microcosm treatments are referred to as 10P, 40N and control, 0NP (Table 1; Fritz et al. 2012). From each plot, S. magellanicum was collected and divided into 4 replicates, yielding a total of 12 samples. All samples collected from the field sites were transported in plastic bags, which were kept in the dark during transport.

\section{$\mathrm{N}$ fertilization treatments}

For clarity, throughout this manuscript deposition is defined as being exposed to the increased anthropogenic load in the field (increased atmospheric deposition), whereas experimental fertilization both in the field and in the lab is defined as watering with $\mathrm{NH}_{4} \mathrm{NO}_{3}$ supplemented water. Prior to incubation in microcosms, fresh weights of mosses were determined, after which they were incubated in glass microcosms that were closed with metal clamps and a rubber O-ring (Bormioli Rocco, Fidenza, Italy). The microcosms consisted of glass jars that had been modified by the addition of a standard crimp-cap serum bottle opening to the glass lid, creating a vessel that was gastight (tested) and accessible through a standard butyl rubber stopper. Most incubations were performed in $1.2 \mathrm{~L}$ glass microcosms containing multiple $S$. magellanicum individuals ( $>10$ individual shoots, $\pm 8 \mathrm{~cm}$ length) to mimic natural density. Due to smaller sample sizes, mosses from the previously fertilized plots $(40 \mathrm{~N}, 10 \mathrm{P}$, and $0 \mathrm{NP} / \mathrm{low}$ $\mathrm{N}$-site mosses from Argentina) were incubated in similar density in microcosms of $0.28 \mathrm{~L}$.

Incubation microcosms were kept in a cooled water basin $\left(16^{\circ} \mathrm{C}\right.$; cryostat) within a climate chamber with artificial light $\left(10 \mathrm{~h}\right.$ dark, $14 \mathrm{~h}$ light, $150 \mu \mathrm{mol} \mathrm{m} \mathrm{s}^{-1}$ PAR, provided by $2 \times 400 \mathrm{~W}$ lamps (Philips, Master Son-T PiaPlus, Belgium)). To minimize site-specific effects other than $\mathrm{N}$ deposition, mosses were acclimatized in this climate room for 8 weeks prior to $\mathrm{N}$ fertilization treatments, during which water in the microcosms was replaced three times a week by fresh $\mathrm{N}$-free artificial rainwater (composition see Table S1), keeping the water level stable at $1 \mathrm{~cm}$ below the capitula $(300 \mathrm{ml}$ for large microcosms; $60 \mathrm{ml}$ for small microcosms; $\mathrm{pH}$ range 4.0-4.5). Hereafter, half of all replicates of each experiment were randomly assigned to receive $\mathrm{N}$ 
fertilized rainwater three doses per week, $1.282 \mathrm{~kg} \mathrm{~N}$ ha per watering moment, equivalent to $200 \mathrm{~kg} \mathrm{~N}^{-1}$ year $^{-1}$ as $\mathrm{NH}_{4} \mathrm{NO}_{3}$ (for composition see Table $\mathrm{S} 1$ ), and the other half were kept as control receiving unamended artificial rainwater (for composition see Table S1). During the treatment phase (16 days), mosses were sprinkled with artificial rainwater three times a week.

Acetylene reduction assays and ${ }^{15} \mathrm{~N}-\mathrm{N}_{2}$ labelling experiments

Activity of the nitrogenase enzyme was measured by the acetylene reduction assay (ARA). The glass microcosms used for moss incubations were closed with red butyl rubber stoppers and aluminium crimp caps to enable gas sampling with a syringe. Headspace volumes were calculated as net volume left after subtracting the volume of added artificial rainwater and fresh weight of the plant from the total volume. Subsequently, acetylene was added to a final concentration of $5 \%(\mathrm{v} / \mathrm{v})$ in the air headspace.

Acetylene $\left(\mathrm{C}_{2} \mathrm{H}_{2}\right)$ reduction and ethylene $\left(\mathrm{C}_{2} \mathrm{H}_{4}\right)$ production were analysed with a Varian Star 3400 gas chromatograph (GC), using a flam-ionization detector and a Porapak N packed GC column $(1.8 \mathrm{~m} \times 2 \mathrm{~mm})$ with helium (He) as carrier gas (Khadem et al. 2010). Methane $\left(\mathrm{CH}_{4}\right)$ is detected as well by this system. Gas samples $(50 \mu \mathrm{l})$ of each of the incubated samples were taken four times within $60 \mathrm{~h}$, after which microcosms were opened again. Nitrogenase activity was determined as ethylene production rates, which were calculated from the linear part of the slope of these four measurements. By doing so, multiple nitrogenase activity assays could be performed over time in a non-destructive manner. Nitrogenase activity was determined two times at the end of the acclimatization period (resp. $13(t=-13)$ and 5 days $(t=-5)$ prior to $\mathrm{N}$ fertilization) and $8(t=+8)$ and 16 days $(t=+16)$ after start of the $\mathrm{N}$ fertilization treatment $(t=0)$. Only nitrogenase activity rates of the different treatments from day +8 and +16 were used for further comparisons and correlation analysis.

To convert ethylene production rates to $\mathrm{N}_{2}$ fixation rates, ${ }^{15} \mathrm{~N}_{2}$ labelling experiments were performed on incubations that still showed nitrogenase activity at the end of the experiment (field control samples from both high-N and low-N sites and 10P samples). These experiments could only be performed at the end of the incubation, as they require destructive sampling. Incubations were split and mosses were incubated for $48 \mathrm{~h}$ either with ${ }^{15} \mathrm{~N}_{2}(5 \% v / v$ headspace) or with both ${ }^{15} \mathrm{~N}_{2}$ (5\% $\% / v$ headspace) and acetylene $(5 \% v / v$ headspace) to check for potential inhibition by acetylene, and a sample was kept as ${ }^{15} \mathrm{~N}_{2}$ background control. Ethylene production was measured as described above. To determine ${ }^{15} \mathrm{~N}_{2}$ uptake, mosses were collected for $\delta \mathrm{N}$ determination of the background and the enriched plant material after $48 \mathrm{~h}$, segmented into three parts $(0-2 \mathrm{~cm}$ from top, $2-4 \mathrm{~cm}$ and $4-6 \mathrm{~cm})$ and dried $\left(72 \mathrm{~h}\right.$ at $\left.70{ }^{\circ} \mathrm{C}\right)$. Moss samples were grinded for $2.5 \mathrm{~min}$ at $30 \mathrm{~Hz}$ with a stainless steel bead ( $\varnothing 5 \mathrm{~mm}$ ) using a Retsch MM200 ball mill (Retsch, Haan, Germany). 12 to $15 \mathrm{mg}$ of each sample was transferred into a $5 \times 8 \mathrm{~mm}$ tin cup and combusted by flash combustion $\left(1800{ }^{\circ} \mathrm{C}\right)$ on a CNS analyzer (EA 1110 Carlo Erba - Thermo Fisher Scientific) coupled to an Isotopic Ratio Mass Spectrometer (Finnigan DeltaPlus, interface Conflo III). Conversion factors were calculated according to Leppänen et al. (2013). Background ${ }^{15} \mathrm{~N}_{2}$ levels were uniform, for the 10P mosses average $\Delta 15 \mathrm{~N} / 14 \mathrm{~N}(\%)$ was $0.797 \pm 0.396$. Since the results of the heavy isotope labelling did not generate one stable conversion factor due to large variations, nitrogenase activity rates were not converted to corresponding $\mathrm{N}_{2}$ fixation, but are expressed as the directly measured ethylene production rates throughout this study.

\section{Plant and porewater analyses}

To check for potential abiotic changes and nutrient contents of the respective porewater and peat moss, peat moss samples were collected in duplicate before $\mathrm{N}$ fertilization and 1 week after the start of $\mathrm{N}$ fertilization, each time directly before acetylene reduction assays were performed. Samples were oven-dried, milled and combusted as described above. Combustion products from $5 \mathrm{mg}$ dry biomass were separated on a Porapak QS-column and analyzed for total $\mathrm{C}$ and $\mathrm{N}$ content. One week after the start of the $\mathrm{N}$ treatments, porewater samples were taken before watering from the microcosms, using rhizons (pore size $2 \mu \mathrm{m}$; Rhizosphere Research Products, Wageningen the Netherlands). Element concentrations of $\mathrm{Na}, \mathrm{K}, \mathrm{P}$ in the porewater $\left(10 \mathrm{~mL}\right.$, acidified with $0.1 \mathrm{~mL} 65 \% \mathrm{HNO}_{3}$ ) were analyzed in duplicate by inductively coupled plasma-optical emission spectroscopy (ICP-OES iCAP 6000, Thermo Fischer Scientific, Carlsbad, USA). 
Molecular analyses

\section{DNA extraction and nifH amplification}

Total DNA was extracted only from intact S. magellanicum plants that were deprived of $\mathrm{N}$ by growth in the greenhouse (originating from both the low and the high $\mathrm{N}$ deposition site). These samples were collected 4 weeks after the start of the acclimatization period, before acetylene reduction assays. Three moss individuals were grinded using pestle, mortar and liquid $\mathrm{N}_{2}$, of which $0.5 \mathrm{~g}$ fresh weight was used for DNA extraction using the Powersoil DNA isolation kit (MO BIO laboratories, Carlsbad, USA), with minor adaptation: in order to increase the final DNA concentration the elution buffer was added in three portions (in total $100 \mu \mathrm{L}$ ), instead of at once. After each addition $(33.3 \mu \mathrm{L})$ the sample was briefly centrifuged.

A fragment of the nifH gene (360 bp) was amplified by polymerase chain reaction (PCR) in a nested approach: the primary step included the forward primer 19F (5'-GCIWTYTAYGGIAARGGIGG-3'; Ueda et al. 1995 ) and the reverse primer nifH3 (5'-ATRTTRTTNGCNGCRTA-3; Zani et al. 2000); in the second step, the forward primer nifH 1 (5'-TGYGAYCCNAARGCNGA-3) and the reverse primer nifH2 (5'-ANDGCCATCATYTCNCC-3; Zehr and McReynolds 1989) were used. For PCR, PerfCTa Quanta master mix (Quanta Biosciences, Gaithersburg, USA) was used. Both PCR protocols started with an initial denaturation step of $98^{\circ} \mathrm{C}$ for $5 \mathrm{~min}$, followed by 30 cycles of denaturation at $95^{\circ} \mathrm{C}$ for $30 \mathrm{~s}$, annealing at $55{ }^{\circ} \mathrm{C}$ for $1 \mathrm{~min}$, and elongation at $72{ }^{\circ} \mathrm{C}$ for $1 \mathrm{~min}$; completed by a final elongation step at $72^{\circ} \mathrm{C}$ for $10 \mathrm{~min}$. Nested PCR was performed with $1 \mu \mathrm{L}$ PCR product of the first PCR. Correct length of both PCR products was checked with gel electrophoreses (GE) on an agarose gel ( $1 \%$, runtime of $1 \mathrm{~h}$ at $60 \mathrm{mV}$ ). Products of the nested PCR with correct lengths (360 base pairs (bp)) were used for amplicon sequencing.

\section{Amplicon sequencing}

Amplicon sequencing of nested PCR products was done using the Ion Torrent Personal Genome Machine ${ }^{\mathrm{TM}}$ (Life technologies, Carlsbad, USA). Products were prepared for sequencing following the manufacturers protocol (MAN0006846 Revision 3.0) using the Ion Plus Fragment Library Kit (Life technologies, Carlsbad,
USA) and the Ion Xpress ${ }^{\mathrm{TM}}$ Barcode Adapter Kits 1-2 (Life technologies, Carlsbad, USA). DNA products of several PCR-reactions of the same sample were pooled to obtain sufficient amounts of DNA. First, PCR products were purified using magnetic beads (Agencourt ${ }^{\circledR}$ AMPure ${ }^{\circledR}$ XP Kit, Beckman Coulter, Brae, USA) and magnetic rack (DynaMagTM_2 magnet). After each following step purification of the DNA fragments was performed using this method.

After determination of purity and concentration using the Bioanalyzer ${ }^{\circledR} 2100$ and the High sensitivity DNA kit (Agilent Technologies, Santa Clara, USA), DNA fragments of the same sample were pooled in equimolar amounts, to a final concentration of $50 \mathrm{ng}$ DNA $\mu \mathrm{L}^{-1}$. Next, DNA fragments were end-repaired, adapters containing specific barcodes (for each sample a different barcode) were ligated, followed by a nick-repair. Finally, amplification (6 cycles, according to manufacturer's protocol) was performed, followed by quantification and a purity check of the product using the Bioanalyzer $^{\circledR} 2100$ and the High sensitivity DNA kit (Agilent Technologies, Santa Clara, USA). All barcoded samples for sequencing were pooled in equimolar amounts to a final concentration of 26 pM DNA. Pooled fragments were amplified on Ion Sphere particles using the Ion One Touch ${ }^{\mathrm{TM}}$ Instrument and Ion One Touch $^{\mathrm{TM}} 400$ Template Kit (Life Technologies, Carlsbad, USA) according to the manufacturer's instructions. After enrichment of the Template-Positive Ion Sphere ${ }^{\mathrm{TM}}$ Particles using the Ion One Touch ${ }^{\mathrm{TM}}$ ES (Life Technologies, Carlsbad, USA), the spheres were loaded on an Ion $314^{\mathrm{TM}}$ v2 Chip. Subsequently, DNA fragments were sequenced using the Ion PGM ${ }^{\mathrm{TM}} 400$ Sequencing Kit according the manufacturer's instructions (MAN0007242 Revision 2.0).

\section{Amplicon sequence analysis}

The amplicon library (NCBI SRA database project number PRJNA280035, samples SAMN03454249, SAMN03454250) yielded 188,517 reads with an average read length of 266 basepairs (bp) from the low $\mathrm{N}$ deposition site and 197,813 with an average length of $281 \mathrm{bp}$ from the high $\mathrm{N}$ deposition site. Prior to clustering, the reverse complements were generated for reads starting with the reverse primer, using the 'reverse.seqs' function in mothur (1.22.2; Schloss et al. 2009). Reads were quality-filtered, so that reads shorter than $320 \mathrm{bp}$ and having more than two expected errors were 
removed (12.6\%; Fastq filter command USEARCH; Edgar 2010). Next, amplicon sequences were dereplicated, sorted according to number of replicate sequences belonging to the representative, followed by length sorting, after which the remainder of 164,235 reads were clustered using UCLUST (Edgar 2010) at a distance level of $10 \%$ (nucleotides). Resulting OTU-representatives (centroids) were tested for chimeras using UCHIME (Edgar et al. 2011). All OTU-representative sequences were subsequently imported into ARB (Ludwig et al. 2004), translated into protein sequences in the correct reading frame, aligned and used for phylogenetic analysis using the nifH database described in Gaby and Buckley (2014). Neighbour-joining trees were calculated based on the amino acid alignment (alignment position 179-368) using the neighbour-joining algorithm and Kimura correction implemented in ARB.

\section{Statistical analyses}

For the high and low N-deposition samples, assumptions of normality for all data (acetylene reduction (ARA), C and N content, Porewater concentrations, $\mathrm{pH})$ were tested using the Shapiro-Wilk test to check for normal distribution, and homogeneity of variances was tested with Levene's test. To analyze the data from $0 \mathrm{NP} / 10 \mathrm{P} / 40 \mathrm{~N}$ plots, the Fligner-Killeen test was used, because of the small number of replicates, since this test is more robust with respect to departures from normality. Non-normal distributed data was transformed to approach a normal distribution, either by square root transformations or by $\ln$-transformations. When parametrical conditions were not met, a non-parametric KruskalWallis test was applied (i.e. for the $\mathrm{N}$ content data).

Differences in nitrogen fixation activity, $\mathrm{C}$ content and porewater data were all analyzed by three-way ANOVA, followed by a Tukey Honest Significant Differences (HSD) test. To test differences in nitrogenase activity measurements and $\mathrm{N}$-fertilization effects, a two-way ANOVA was performed. Type I was applied to the formerly fertilized plots (0NP, $10 \mathrm{P}, 40 \mathrm{~N})$; factors used were origin $(0 \mathrm{NP}, 10 \mathrm{P}$ or $40 \mathrm{~N})$, and treatment (N-fertilized or control). A type III three-way ANOVA was applied to test for differences between the different samples in the high versus low N-deposition site experiment, correcting for unbalanced design in the comparison. For both experiments test were carried out separately for the two periods: acclimatization period $(t=13$ and $t=5$ days) and $\mathrm{N}$ fertilization period $(t=+8$ and $t=$ +16 days). Factors used in the ANOVA for the high-low $\mathrm{N}$ deposition site were: origin (high or low $\mathrm{N}$ site), $\mathrm{N}$ deprivation ( $\mathrm{N}$-deprived or field), and treatment (N-fertilized or control; also see Table S8). Since the ANOVA tests showed high numbers of interactions on the ARA data, the $\mathrm{N}$-fertilization treatment effect was also tested using a paired t-test on a priori paired data of the $\mathrm{N}$-fertilization period.

Data shown here are the averages of the relevant replicates (mean \pm standard error). Correlations between ARA data and $\mathrm{N}$ contents, $\mathrm{C}$ contents or porewater nutrient levels of the formerly fertilized plots were analyzed using Spearman's test, which is more robust for small number of replicates. All statistical analyses were performed using R version 2.15.2 (R Development Core Team 2012), and significance levels were indicated as follows: $=p<0.1, *=p<0.05, * *=p<0.01$, $* * *=p<0.001$.

\section{Results}

N-accumulation in Sphagnum

Sphagnum N content was 2.5 times lower for mosses from the low $\mathrm{N}$ site than for the high $\mathrm{N}$ site $\left(\chi^{2}=6.86\right.$, $p<0.01$; Fig. 1). This strong difference in $\mathrm{N}$ contents had disappeared in $\mathrm{N}$-deprived mosses. For the formerly fertilized mosses from Argentina, $\mathrm{N}$ content also

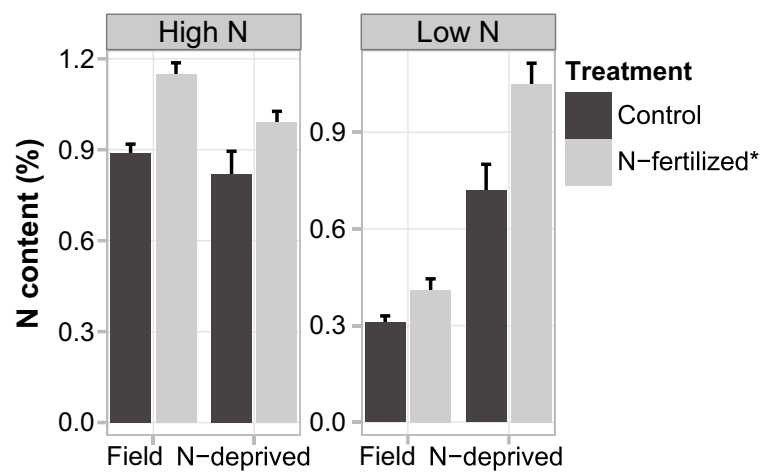

Fig. 1 N content (\%) in Sphagnum samples freshly collected from the field and from Sphagnum samples after 3 years of N-deprived greenhouse incubations originating from the high- and low $\mathrm{N}$ deposition sites, and its change upon treatment with high $\mathrm{N}$ fertilization. Bars represent the mean \pm SE ( 3 replicates per sample). Effects of $\mathrm{N}$ fertilization and of the $\mathrm{N}$ deposition history were tested with Kruskal-Wallis (resp. $\chi^{2}=11.1368, p<0.001$; $\chi^{2}=6.8612, p<0.01$ ) 
differed, being lowest for the 0NP-plot mosses and highest for the $40 \mathrm{~N}$-plot mosses $(p<0.001$; Fig. 2). Overall, both $\mathrm{N}$ and $\mathrm{P}$ fertilization increased the $\mathrm{N}$ content of Sphagnum tissue compared to the unfertilized mosses, while $\mathrm{C}$ content was not affected $\left(\mathrm{F}_{1,20}=21.15\right.$, $p<0.001)$. After short-term laboratory $\mathrm{N}$ fertilization, the $\mathrm{N}$ content increased by $25 \%$ in mosses from both low- and high- $\mathrm{N}$ deposition sites $\left(\chi^{2}=11.14, p<0.001\right.$; Fig. 1), and by $35 \%$ in mosses from the formerly fertilized plots $\left(\chi^{2}=4.44, p<0.05\right.$; Fig. 2$)$. For the formerly fertilized plots, it was apparent that the increase in $\mathrm{N}$-content in the 10P mosses was much higher than for the $40 \mathrm{~N}$ or $0 \mathrm{NP}$ mosses (Fig. 2). In none of the experiments did the pattern observed in $\mathrm{N}$ content of the mosses correlate with nitrogenase activity.

\section{Porewater $\mathrm{Na}, \mathrm{K}$ and $\mathrm{P}$ concentrations}

Experimental $\mathrm{N}$ fertilization led to increased porewater concentrations of potassium $(\mathrm{K})$ and sodium $(\mathrm{Na})$ in both experiments (Table S2 and Table S3). Both K and $\mathrm{Na}$ concentrations were generally three times lower in microcosms with mosses from the field than those with $\mathrm{N}$-deprived mosses (resp. $F_{1,14}=22,25, p<0.001$ $\left.F_{1,14}=11.39, p<0.01\right)$. Porewater $\mathrm{P}$ concentrations of mosses from the low $\mathrm{N}$ deposition field site were very low, only $10 \%$ of the $\mathrm{P}$ concentration in all other microcosms $\left(F_{1,14}=9.55, p<0.01\right)$. Moreover, in these microcosms the $\mathrm{P}$ concentrations did not further decrease upon $\mathrm{N}$ fertilization, unlike in the other treatments, where $\mathrm{P}$ concentrations decreased by $33 \%$. In

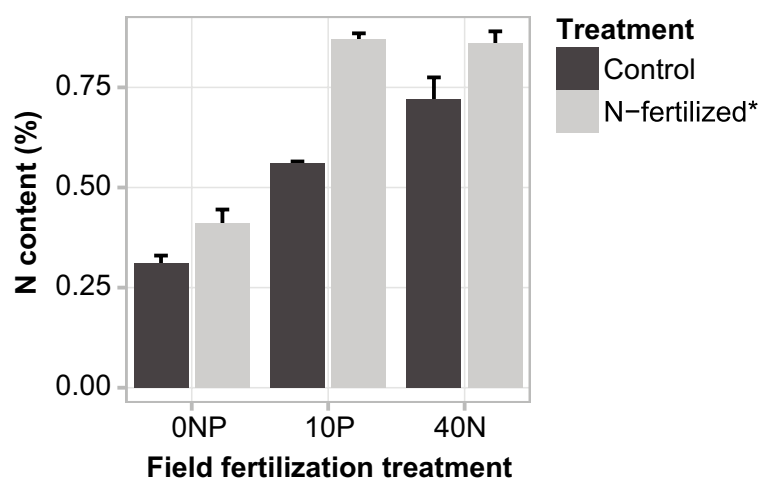

Fig. 2 N content (\%) in Sphagnum samples from past long-term in situ fertilization experiments from the low $\mathrm{N}$ deposition field site $(0 \mathrm{NP}, 10 \mathrm{P}, 40 \mathrm{~N})$, either treated with $\mathrm{N}$ fertilization or kept as control. Bars represent the mean \pm SE ( 2 replicates per plot). Effects of $\mathrm{N}$ fertilization and of the $\mathrm{N}$ deposition history on the $\mathrm{N}$ content were tested using Kruskal-Wallis $\left(\chi^{2}=4.443, p<0.05\right.$ and $\left.\chi^{2}=15.687, p<0.001\right)$ microcosms with mosses from the formerly $\mathrm{N}$-fertilized plot $(40 \mathrm{~N}), \mathrm{P}$ concentrations became remarkably higher upon $\mathrm{N}$ fertilization $\left(F_{2,8}=3.38, p=0.086\right.$; supplementary table S3), when compared to the other treatments. Furthermore, nitrogenase activities in this treatment were negatively correlated with $\mathrm{P}$ concentrations in porewater (Spearman $c=-0.71, p=0.01, n=12$ ), indicating that higher $\mathrm{P}$ uptake from pore water was linked to higher $\mathrm{N}_{2}$ fixation rates.

Nitrogenase activity in mosses derived from low and high $\mathrm{N}$ deposition sites

The nitrogenase activity was seven times higher for the low N site than for the high N site (Fig. 3a). During incubation and repeated ARA, however, activity strongly decreased for the low $\mathrm{N}$ site, while it remained stable for the high $\mathrm{N}$ site (Table S5). Furthermore, during acclimatization nitrogenase activity was on average two times lower in $\mathrm{N}$-deprived samples (71 $\pm 21 \mathrm{C}_{2} \mathrm{H}_{4} \mathrm{~g}^{-1} \mathrm{dw}$ day $^{-1}$ ). Prior to $\mathrm{N}$ fertilization, nitrogenase activity was determined twice, showing an overall average of $116 \pm 25 \mathrm{C}_{2} \mathrm{H}_{4} \mathrm{~g}^{-1} \mathrm{dw}$ day ${ }^{-1}$. A week before start $(t=-5)$ of $\mathrm{N}$-fertilization, nitrogenase activity measurements showed no difference between replicates of the different mesocosms or between the two sites $\left(\mathrm{F}_{1,18}=3.96, p=0.06\right)$. At $t=+8$ the activity was 40 times higher in the mosses from the high $\mathrm{N}$ deposition site compared to the low $\mathrm{N}$ deposition site (see Fig. 3b) as a result of the stronger decrease. Throughout the experiment, no $\mathrm{CH}_{4}$ formation was detected in any of the incubations.

Short-term $\mathrm{N}$ fertilization effects on nitrogenase activity in mosses from low- and high $\mathrm{N}$ deposition sites

$\mathrm{N}$ fertilization reduced nitrogenase activity in mosses from both low and high $\mathrm{N}$ deposition sites, and also for $\mathrm{N}$-deprived mosses. Already 8 days after the start of $\mathrm{N}$ fertilization $(t=+8)$, all $\mathrm{N}$ fertilized microcosms showed lower nitrogenase activity rates than controls (Fig. 3b). For the field mosses, 8 days of $\mathrm{N}$ fertilization led to an 80 times lower $\mathrm{N}_{2}$ fixation activity rate (1.4 $\pm 0.55 \mathrm{nmol} \mathrm{C}_{2} \mathrm{H}_{4} \mathrm{~g}^{-1} \mathrm{dw}_{\text {day }}{ }^{-1}$ ) compared to their controls $\left(113 \pm 30 \mathrm{nmol} \mathrm{C}_{2} \mathrm{H}_{4} \mathrm{~g}^{-1} \mathrm{dw}_{\text {day }}{ }^{-1} ; t_{(9.0)}=3.42\right.$, $p<0.01)$. A similar trend of $\mathrm{N}$ fertilization was observed for the $\mathrm{N}$-deprived moss incubations $\left(t_{(13.1)}=1.72\right.$, $p=0.055)$. 


\section{Treatment}

Control

$\mathrm{N}$-fertilized*

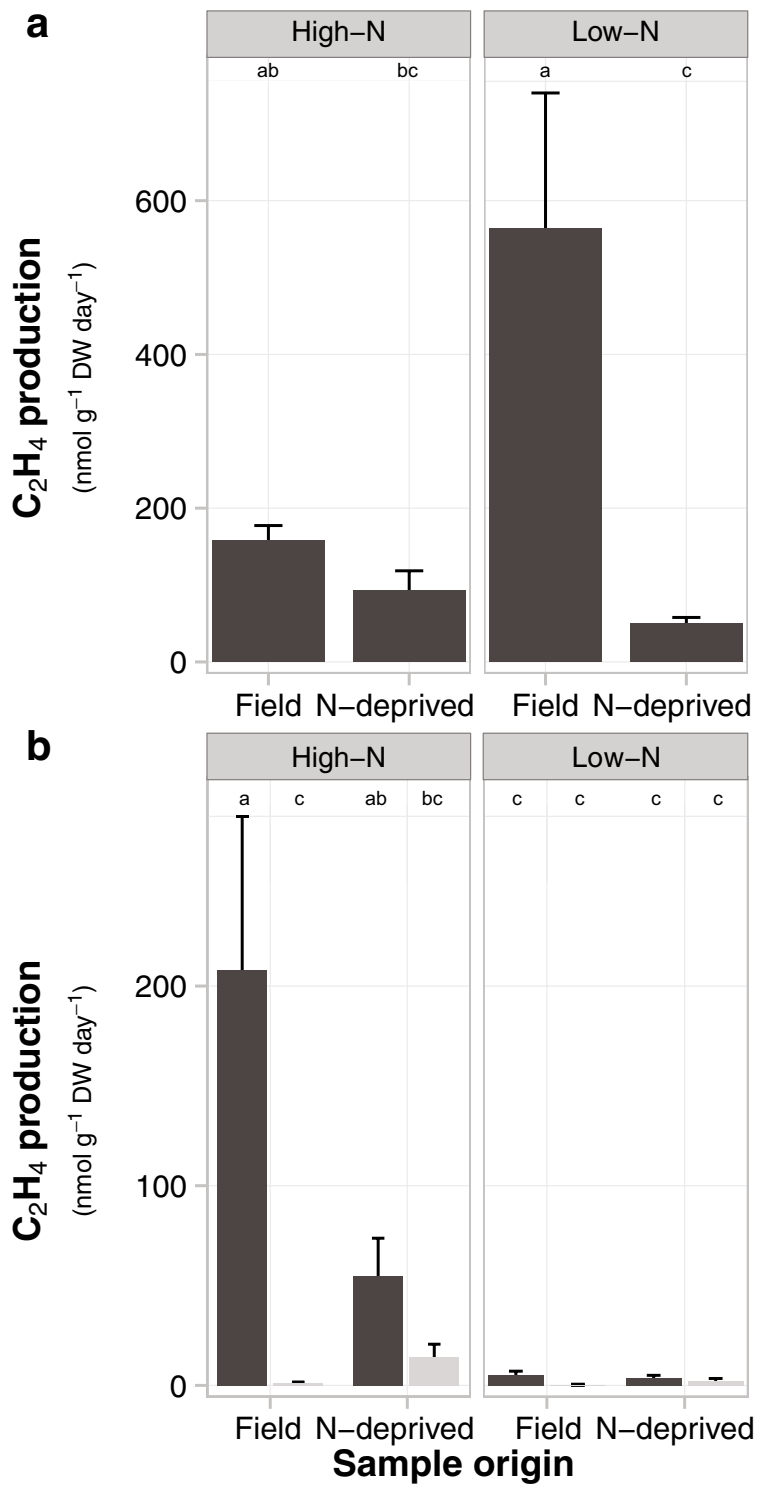

Fig. $3 \mathrm{C}_{2} \mathrm{H}_{4}$ production rates of mosses (mean $\pm \mathrm{SE}$ ) from low- and high $\mathrm{N}$ deposition sites, during acclimatization period (a, $n=6)$, where different letters indicate significant differences as tested by ANOVA followed by TukeyHSD $\left(\mathrm{F}_{1,40}=24.06, p<0.001\right)$, and $\mathrm{C}_{2} \mathrm{H}_{4}$ production rates during the fertilization period $(\mathbf{b}, n=3)$, where different letters indicate significant differences as tested by ANOVA analysis followed by TukeyHSD, with significant interactions between treatment and $\mathrm{N}$-deposition site $\left(\mathrm{F}_{1,36}=9.79, p<0.01\right)$ and between treatment and $\mathrm{N}$-deprivation $\left(\mathrm{F}_{1.36}=9.0381, p<0.01\right)$. The treatment effect was tested separately on a priori paired data using a paired t-test for field $\left(t_{(9.0)}=3.42, p<0.01\right)$ and $\mathrm{N}$-deprived samples $\left(t_{(13.1)}=1.72, p=0.055\right)$
Short-term $\mathrm{N}$ fertilization effects on nitrogenase activity in mosses with a history of $\mathrm{P}$ or $\mathrm{N}$ fertilization

Similar to the results for low and high $\mathrm{N}$ deposition sites, nitrogenase activity decreased over time for all incubations with mosses from former fertilization plots 10P, $40 \mathrm{~N}$ and 0NP. At the very beginning of the acclimatization period, Sphagnum-associated nitrogenase activity in the 0NP-microcosms showed almost three times higher activity $\left(1012 \pm 101 \mathrm{nmol} \mathrm{C}_{2} \mathrm{H}_{4} \mathrm{~g}^{-1} \mathrm{dw}_{\text {day }}{ }^{-1}\right)$, than for incubations from the fertilized plots $10 \mathrm{P}$ and $40 \mathrm{~N}$ (respectively $368 \pm 14$ and $340 \pm 53 \mathrm{nmol} \mathrm{C}_{2} \mathrm{H}_{4} \mathrm{~g}^{-1} \mathrm{dw}$ day $^{-1}$; $\left.F_{2,18}=17.55, p<0.0001\right)$. Five days prior to start of the $\mathrm{N}$-fertilization treatment, nitrogenase activities had decreased compared to levels at which nitrogenase activities started, but the activities were similar between the different microcosms $\left(0 \mathrm{NP} / 10 \mathrm{P} / 40 \mathrm{~N} \mathrm{~F}_{2,9}=1.59, p=0.26\right)$.

During $\mathrm{N}$-fertilization, nitrogenase activities in all but the 10P samples decreased, and even became undetectable in the $40 \mathrm{~N}$-microcosms $\left(F_{2,8}=24.84, p<0.001\right.$; Fig. 4). In contrast, 10P-microcosms showed on average two times higher nitrogenase activity after $\mathrm{N}$ fertilization $\left(118 \pm 7 \mathrm{C}_{2} \mathrm{H}_{4} \mathrm{~g}^{-1} \mathrm{dw}\right.$ day $\left.^{-1}\right)$ than their unfertilized controls $\left(50 \pm 17 \mathrm{nmol} \mathrm{C}_{2} \mathrm{H}_{4} \mathrm{~g}^{-1} \mathrm{dw}\right.$ day $^{-1} ; t_{4.04}=3.63$, $p<0.05)$.

${ }^{15} \mathrm{~N}$ label incorporation

The ${ }^{15} \mathrm{~N}$ incorporation method to assess $\mathrm{N}_{2}$ fixation rates could only be used at the end of the incubation experiments, as it required destructive sampling. Only in mosses from the 10P-plot, both a clear ${ }^{15} \mathrm{~N}_{2}$

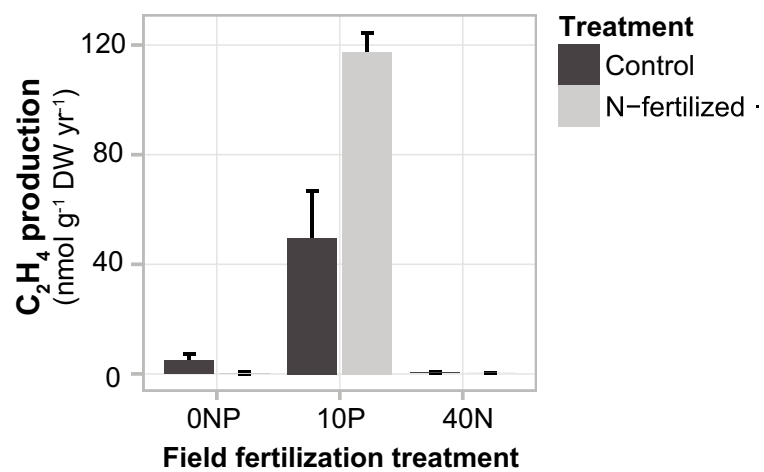

Fig. 4 Effect of $\mathrm{N}$ fertilization on $\mathrm{C}_{2} \mathrm{H}_{4}$ production rates of mosses from past long-term in situ fertilization experiments with either P (10P), $\mathrm{N}(40 \mathrm{~N})$ or treated with unamended bog water (0NP). Displayed values indicate mean $\mathrm{C}_{2} \mathrm{H}_{4}$ production $\pm \mathrm{SE}$ $(n=3)$. The treatment effect was tested on a priori paired data using a paired t-test $\left(\mathrm{t}_{(3.13)}=2.220, p=0.055\right)$ 
incorporation signal and acetylene reduction rate was obtained. Here, uptake of ${ }^{15} \mathrm{~N}_{2}$ was lower in incubations with both acetylene and ${ }^{15} \mathrm{~N}_{2}$ compared to incubations with only ${ }^{15} \mathrm{~N}_{2}$ (Fig. 5; $\mathrm{F}_{1,12}=11.92, p<0.01$ ), indicating competition and/or inhibition by acetylene. The weighted average of the ${ }^{15} \mathrm{~N}_{2}$ incorporation in mosses incubated with both acetylene and ${ }^{15} \mathrm{~N}_{2}$ generated a conversion factor of 3.11 ( $\mathrm{mol} \mathrm{N} 2$ fixed $/ \mathrm{mol} \mathrm{C}_{2} \mathrm{H}_{2}$ reduced) similar to those found in other studies (Leppänen et al. 2013), although showing high variation $(\mathrm{SEM}=1.1)$.

Molecular analysis of microbial diazotrophic communities

Clustering of the nifH amplicon sequences derived from the $\mathrm{N}$-deprived mosses of the low- and high $\mathrm{N}$ sites was performed at $10 \%$ nucleotide-distance level. The resulting 73 nifH OTU-representatives were analyzed at amino-acid level (Suppl. table S4). Ninety-five percent of all reads were covered by 20 OTU-representatives, with the remaining 53 OTU-representatives had only a low coverage (Fig. 6). The OTU-representatives clustered in three of the four main groups of the nifH gene diversity (Zehr et al. 2003) and the diversity considerably differed between mosses from the two sites.

Overall the diazotrophic community consisted mostly of proteobacteria, but showed distinct diversity for the mosses originating from two different geographical

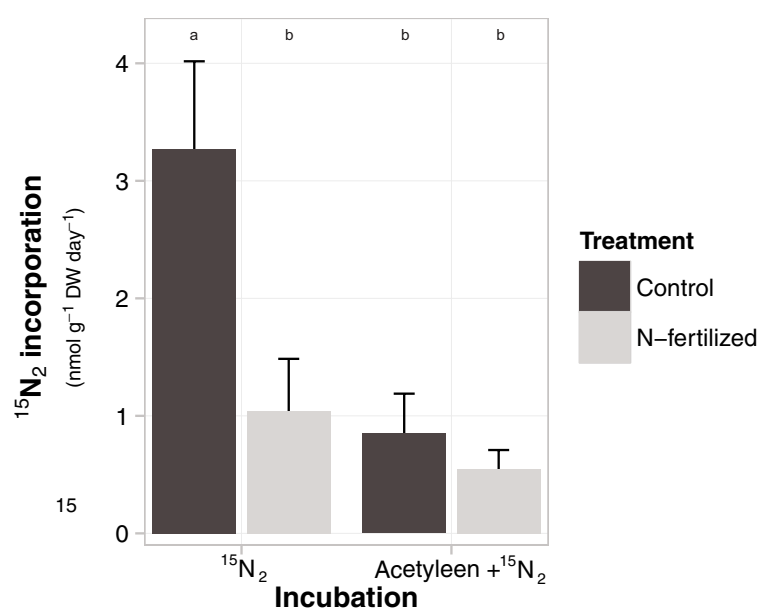

Fig. $5 \mathrm{~N}_{2}$ fixation rates $\left({ }^{15} \mathrm{~N}_{2}\right.$ labelling) in 10P-plot mosses (mean $\pm \mathrm{SE}, n=6$ ). Comparison of $\mathrm{N}_{2}$ fixation rates in the different incubations, only with ${ }^{15} \mathrm{~N}_{2}$ (left), or incubated with ${ }^{15} \mathrm{~N}_{2}$ and acetylene (right), and of the different treatments (control or Nfertilized). $\mathrm{N}$-fertilization and incubation type both showed a significant effect (resp. $\mathrm{F}_{1,12}=8.69, p<0.05 ; \mathrm{F}_{1,12}=11.92, p<0.01$ ) regions. Cyanobacterial nitrogenases were only present in $S$. magelanicum from the high $\mathrm{N}$ deposition site (Fig. 6, Cluster I; OTU-representatives 15, 33, 41, 43, 62; related to Calothrix, Leptolyngbya, Trichormus). Furthermore, the diazotrophic community within the high $\mathrm{N}$ deposition differed from the low $\mathrm{N}$ deposition site in that many OTU-representatives showed high similarity to uncultured, environmental $n i f H$ representatives. Within cluster I and III, several OTUs, mostly from the high $\mathrm{N}$ deposition site, were related to uncultured groups: Within cluster II groups such as from a Russian peat bog (OTU 17 and 18), from peat-rhizosphere-soil environments (OTU 13, 21, 26 and 72), estuarine sea water (OTU 9, 27 and 37); Within cluster I the nifH representatives were related to clusters of uncultured nifH sequences derived from peat, soil, rhizosphere and glaciers (Cluster I - OTU 34, 40, 44, 48, 56, 58, 60 and 68).

The diazotrophic community in S. magellanicum from the low $\mathrm{N}$ deposition was dominated by reads associated to Bradyrhizobiaceae, Rhizobiaceae, Rhodospirilalles and Chlorobiales. The difference with the high $\mathrm{N}$ deposition site was apparent in that low $\mathrm{N}$ deposition site had the highest number of reads clustering closely to Verrucomicrobial nitrogenases (cluster III; OTU 3, 4, 7, 8, 14, 16, 19, 20, 23 and 28). Furthermore, three highly abundant OTU-representatives (OTU 5, 32 and 36) that were only present in mosses from the low $\mathrm{N}$ deposition site formed a new distinct group within cluster III, in between Desulfobacterales and environmental nifH sequences previously found in peat.

The only OTU-representatives with similarity to cluster II, which contained functional alternative nitrogenases $($ anf $H)$ and nitrogenases of archaeal origin, were OTU 12 and 64. OTU 12 was overall the most abundant OTU-representative with most reads originating from the low $\mathrm{N}$ deposition site. OTU-representatives 12 and 64 clustered in between nifH groups from Alphaproteobacteria and Firmicutes of Cluster II, but not close to alternative nitrogenases.

\section{Discussion}

We studied the effect of $\mathrm{N}$ deposition on the activity of the diazotrophic community in Sphagnum magellanicum. Sphagnum mosses with a history of either low or high $\mathrm{N}$ deposition in the field were investigated with respect to their nitrogenase activities, and this 


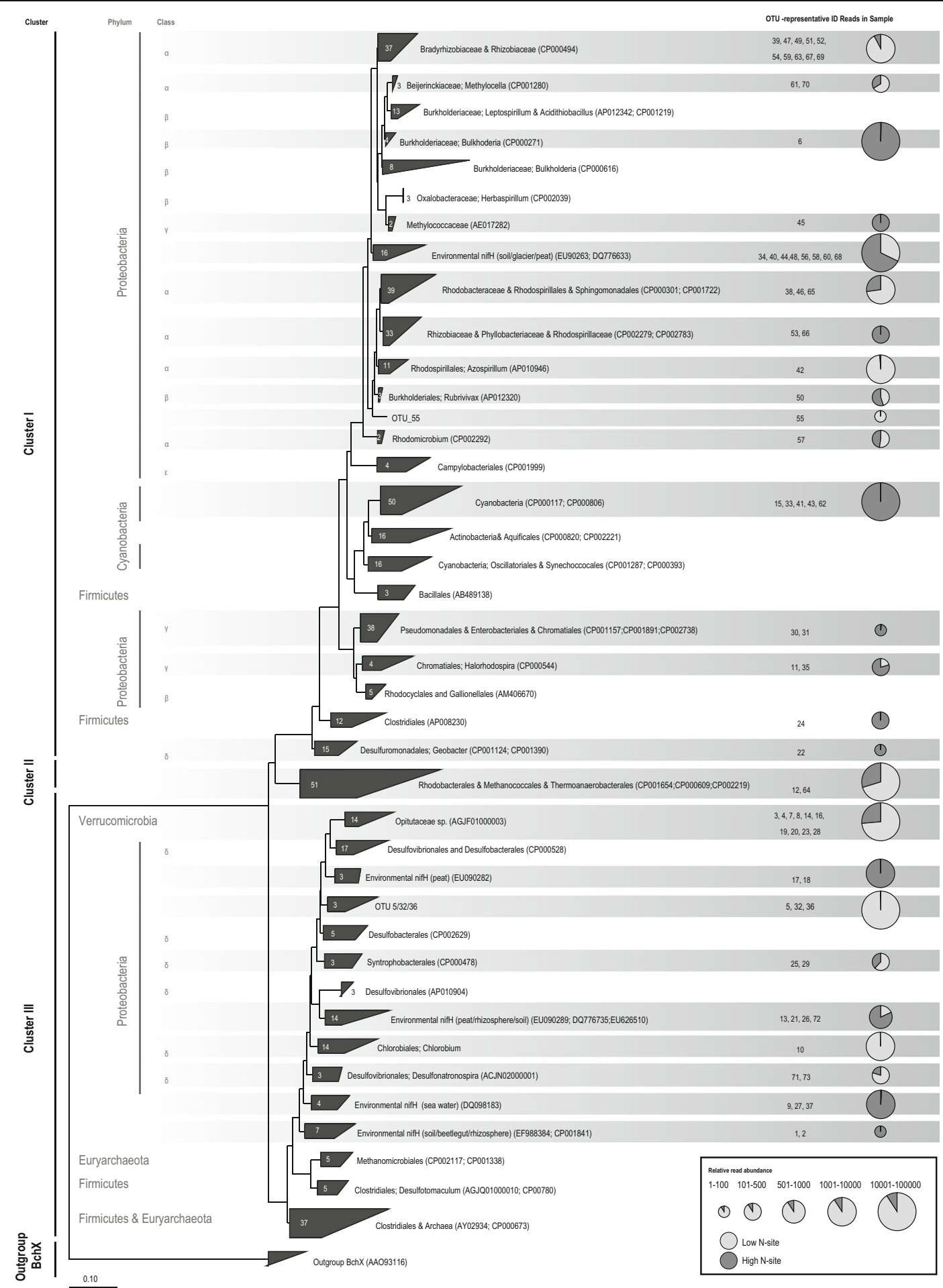

Fig. 6 Phylogenetic relationship of partial nifH sequences, based on the deduced amino acid alignment. The Neighbor joining tree was generated in ARB, showing nifH OTU-representatives generated with USEARCH $($ dist $<0.90)$ and relevant publically availright, as well as relative read abundance of the OTU per sample (low N-site in light grey, high N-site in dark grey). The size of the pie charts indicates read abundance for the OTU-representatives 
was complemented by short-term $\mathrm{N}$ fertilization experiments. In addition, similar experiments were performed on mosses from the same locations that had been deprived for $\mathrm{N}$ for 3 years.

Long- and short-term effects of increased $\mathrm{N}$ deposition

Nitrogenase activity was expected (hypothesis $4, \mathrm{H} 4$ ) to be higher in mosses receiving low $\mathrm{N}$ deposition (pristine site), which was initially indeed the case (Fig. 3a), while $\mathrm{P}$ contents were similar for both sites $(0.27 \mathrm{vs}$. $0.33 \mathrm{mg} \mathrm{g}^{-1}$; Fritz et al. 2012; H.B.M. Tomassen, unpublished results). These results are comparable to observations for nitrogenase activity in forest mosses (Pleurozium spp.) along an $\mathrm{N}$ deposition gradient, where sites with higher $\mathrm{N}$ deposition showed lower $\mathrm{N}_{2}$ fixation rates (Leppänen et al. 2013). Surprisingly however, nitrogenase activity in Sphagnum mosses with a long-term history of low $\mathrm{N}$ deposition strongly decreased upon incubation and repeated ARA, while activity remained equally for the high $\mathrm{N}$ site (see "Methodological considerations" below). Furthermore, experimental, 3-year $\mathrm{N}$ deprivation in the greenhouse did not result in increased nitrogenase activity, unlike what was hypothesized (H2). Changes in the environmental conditions (such as temperature and duration of light) could have contributed to that. When testing short-term effects of $\mathrm{N}$ fertilization, nitrogenase activity decreased in mosses from both sites, as was expected (H1). These negative effects in the $\mathrm{N}$-fertilization period were, however, not observed for mosses with a high $\mathrm{P}$ content (around $1.8 \mathrm{mg} \mathrm{g}^{-1}$ (Fritz et al. 2012)), which is in line with our hypothesis (H3). This lack of negative effects on nitrogenase activity may either indicate a direct regulatory role of $\mathrm{P}$ on $\mathrm{N}_{2}$ fixation rates, or an indirect role due to higher $\mathrm{N}$ demands as a result of higher $\mathrm{P}$ availability. Competition for $\mathrm{N}$ between the plant and different guilds of microorganisms might explain why we observe an increase in nitrogen fixation activity when both $\mathrm{P}$ and $\mathrm{N}$ are highly available. In this scenario, diazotrophs would not be able to successfully compete with the moss and/or other microbes for direct uptake of $\mathrm{N}$ from the environment.

The lack of stimulation of $\mathrm{N}_{2}$ fixation by $\mathrm{N}$ deprivation, and the interaction with $\mathrm{P}$ availability indicated that the effect of $\mathrm{N}$ deposition on $\mathrm{N}_{2}$ fixation is not as straightforward as initially assumed. It indicates that rather than forming a closely regulated symbiosis with their Sphagnum host, $\mathrm{N}_{2}$ fixing microorganisms might live relatively independently within the mosses' hyaline cells. In this case, the plants would only indirectly benefit from diazotrophic activities of the microorganisms they harbor, via increased turnover of $\mathrm{N}$ in the plant-microbe system, as was also postulated by Ho and Bodelier (2015).

Comparing our $\mathrm{N}$-content data of the mosses that were kept as controls in the short-term $\mathrm{N}$ fertilization experiment, with N-content data in Fritz et al. (2012), we observed that the previously fertilized mosses were not $\mathrm{N}$-saturated at start of the $\mathrm{N}$-fertilization treatments and could still increase their $\mathrm{N}$-contents (see supplementary material table 7). Even though in the field porewater $\mathrm{N}$ concentrations were 7 times higher for the high $\mathrm{N}$ site than in the low $\mathrm{N}$ site (20 vs. $2.8 \mu \mathrm{mol} \mathrm{L}{ }^{-1}$; H.B.M. Tomassen, unpublished results and Fritz et al. 2012), the $\mathrm{N}$ content of all mosses in this study increased after short-term $\mathrm{N}$ fertilization and diazotrophic activity decreased, with the highest increase in $\mathrm{N}$ contents seen in the mosses with a high P-content, as hypothesized (5).

The negative feedback of $\mathrm{N}$ fertilization might be regulated at two different levels: at the bacterial cell level, where high $\mathrm{N}$ availability may lead to a down-regulation of energetically costly $\mathrm{N}_{2}$ fixation by negative feedback of $\mathrm{NH}_{4}^{+}$(Dixon and Kahn 2004) or due to nitrite damage (Postgate 1982), or at the level of plant-microbe interactions, e.g. by changing the release of plant exudates as energy-rich substrates for heterotrophic diazotrophs. In a meta-analysis of 92 studies the second mechanism has been demonstrated for rhizospheric communities of vascular plants: higher nutrient availability (including $\mathrm{N}$ ) resulted in lower C-loss via root exudation (Fernández-Martínez et al. 2014). The latter explanation would imply that saturation of the N requirement in Sphagnum would lead to lower diazotrophic activity by limiting the energy supply to endophytes. It warrants further investigation to precisely determine the mechanisms that control the $\mathrm{N}_{2}$ fixing activity of Sphagnum-associated diazotrophs.

Methodological considerations

Apart from the $\mathrm{N}$ deposition effects, an overall decrease in nitrogenase activity over time was observed for the low $\mathrm{N}$ site, unlike for the high $\mathrm{N}$ site. Besides an influence of incubation conditions such as light, nutrient and possibly oxygen availability that are different from field conditions, the repeated exposure to acetylene may well have contributed to the decrease. ARA was 
measured four times during 40 days in the same microcosms. Acetylene is known to inhibit the (methane and ammonium) monooxygenases of methanotrophs and other alkane- and ammonium-utilizing bacteria (De Bont and Mulder 1976), as well as the nitrous oxide reductase of denitrifiers (Yoshinari et al. 1977).

In our experimental set-up, most nitrogenase activity with the ${ }^{15} \mathrm{~N}_{2}$ tracer method was observed in capitula of the moss, a site where previous studies hardly detected methanotrophic activity (Raghoebarsing et al. 2005). Moreover, selective inhibition of methanotrophic diazotrophs by acetylene is unlikely, since no methane and therefore substrate for methanotrophs was provided during the experiments or the acclimatization period of this study, nor was there any formation of methane observed. Therefore, deprivation of methane during the complete experimental phase might have contributed to the observed decrease in $\mathrm{N}_{2}$ fixation activity. Especially for mosses from the low N-deposition site, where the strongest decrease in $\mathrm{N}_{2}$ fixation activity was observed, since for similar pristine sites methanotrophic diazotrophs have been shown to contribute to $\mathrm{N}_{2}$ fixation significantly (Vile et al. 2014).

Lastly, some bacteria have been reported to use the ethylene produced as a substrate for growth (Capone 1993), and ethylene is a plant hormone, which might affect the moss performance (Groen and Whiteman 2014). Together these effects may have caused a shift in the microbial community or in the plant-microbe interaction, resulting in a decrease of nitrogenase activity.

In several other studies, conversion factors between acetylene reduction and $\mathrm{N}_{2}$ fixation rates were calculated by complementing the AR method with ${ }^{15} \mathrm{~N}_{2}$ incorporation, resulting in a wide range of values for conversion factors (Leppänen et al. 2013; Vile et al. 2014; Knorr et al. 2014). Unlike in these studies, repeated measurements of the same microcosms in the present study made the use of the otherwise preferable, but destructive ${ }^{15} \mathrm{~N}_{2}$ uptake method impossible. Comparisons of ethylene production rates from acetylene with $\mathrm{N}_{2}$ fixation rates indicated inhibition of $\mathrm{N}_{2}$ fixation by acetylene (Fig. 5). The variation in conversion factors to calculate $\mathrm{N}_{2}$ fixation rates based on ethylene production rates emphasized the uncertainty when using standard conversion factors. Finally, although endogenous ethylene production is generally not observed in peatlands (Schwintzer 1983; Weber et al. 1983), we cannot exclude it as a confounding factor.
Comparison of diazotrophic communities

The molecular analysis of the diazotrophic community, which was performed only on N-deprived Sphagnum magellanicum mosses, showed clearly distinguishable communities for the mosses of two different origins, still persisting after 3 years of identical growth conditions in the greenhouse. Even though the community of both moss samples may no longer be identical to the original community in the field, it demonstrates a remarkable persistence, or 'memory effect' (Gunderson 2000). Key distinguishing phylotypes were Cyanobacteria, Verrucomicrobia, and several environmental nifH clusters. While Cyanobacteria and OTUs $17 \& 18$ were almost exclusively present in mosses from the high $\mathrm{N}$ site, Verrucomicrobia and OTUs 5, 32 and 36 were most prominently present in mosses with a history of low $\mathrm{N}$ deposition. This finding underlined the need for complementary studies focusing on microbial culturing, as there are no cultured representatives of this entire branch of commonly found Verrucomicrobia yet, and therefore their physiological characteristics are unknown. Studies dedicated to the enrichment and isolation of this group would complement molecular analyses, and yield valuable information on their physiological characteristics that are so far poorly understood.

Several groups of the Sphagnum-associated diazotrophic community abundant in both sites, especially belonging to the Alpha- and Betaproteobacteria, have also been observed in Sphagnum plants from alpine sites and Russian bogs (Zadorina et al. 2009; Bragina et al. 2014). Whereas these may be part of a basic Sphagnum microbiome, specific environmental factors apart from $\mathrm{N}$ availability (i.e. water table dynamics, $\mathrm{O}_{2}, \mathrm{P}$ and $\mathrm{CH}_{4}$ availability), are likely to also have contributed to the differences in the diazotrophic communities. Our findings are in contrast to a study comparing the microbial diversity of two Sphagnum species from three sampling sites in the Alps (Bragina et al. 2011). There it was observed that the same Sphagnum species from different sites harboured similar microbial communities. The clear community differences we found within the same species from Europe and South America questions if this is valid for distances on a global scale. Although long-distance spore (and attached community) dispersal has been documented, it probably nevertheless is so rare that species effects are dominated by geographical effects on community diversity (Shaw et al. 2014). 
Interactions with P-availability

When focusing on the $\mathrm{N}$-fertilization period of this study, the formerly P-fertilized mosses demonstrated higher nitrogenase activity upon $\mathrm{N}$ fertilization, compared to their non-fertilized controls, in stark contrast to all other samples. It is remarkable that even 3 years after cessation of $\mathrm{P}$ fertilization, moss $\mathrm{P}$ content was still higher (Fritz et al. 2012). Since nitrogenase activity only increased in those P-enriched mosses, it is likely that all other samples were P limited. This may particularly affect $\mathrm{N}_{2}$-fixing microorganisms, which generally require more $\mathrm{P}$ than non- $\mathrm{N}_{2}$-fixers (Vitousek et al. 2002). When looking at the effect of $\mathrm{N}$-fertilization on $\mathrm{N}$-content, the steeper increase in $\mathrm{N}$-content in the 10P mosses indicated that $10 \mathrm{P}$ mosses may better retain the applied N, probably because compared to the $0 \mathrm{NP}$ and $40 \mathrm{~N}$ mosses they have less relative P-limitation. Since P had been incorporated into plant tissue, it was most probably no longer directly available to diazotrophs. Therefore we concluded that in case of P- or other relative nutrient limitation in the plants, $\mathrm{N}$ fertilization may not be of benefit to plants, but only lead to a shift in their microbial community and activity. The most probable mechanism explaining the increased nitrogenase activity is increased exudation of energy-rich substances by Sphagnum, which could then enable heterotrophic diazotrophs to increase their $\mathrm{N}$ fixation rates. Furthermore, since nitrogenase activity of the 10P mosses overall was higher than in the $40 \mathrm{~N}$ or $0 \mathrm{NP}$ mosses, our results also confirmed findings by Larmola et al. (2014), who showed that $\mathrm{P}$ availability exerted a strong control on $\mathrm{N}_{2}$ fixation activity.

It is likely that $\mathrm{N}_{2}$ fixation can match the increased $\mathrm{N}$-demand of Sphagnum at higher P availability, as has been discussed for $\mathrm{P}$ addition experiments with feather mosses occurring in boreal forests (Rousk et al. 2013a). $\mathrm{P}$ addition experiments generally did show a stimulating effect on Sphagnum growth (Limpens et al. 2004; Fritz et al. 2012) and in P. schreberi on $\mathrm{N}_{2}$ fixation (Rousk et al. 2013a). In accordance with these studies, the P-fertilized mosses in this study demonstrated an increase of both the $\mathrm{C}$ and $\mathrm{N}$ content upon $\mathrm{N}$ fertilization, which indicated that these mosses, in contrast to all others, could make use of the additional N-load for growth (Fritz et al. 2012). As increased P availability will directly affect both the plant and its microbial community, future experiments are needed to disentangle the capability of Sphagnum to actively regulate diazotrophic activity versus regulation on the microbial community level only.

\section{Conclusions and outlook}

Our study demonstrated that the nitrogenase activity of Sphagnum-associated diazotrophs was clearly negatively affected by $\mathrm{N}$ fertilization. Saturation of the $\mathrm{N}$ demand of the diazotrophic community in combination with the energy costs associated with $\mathrm{N}_{2}$ fixation, and potentially also N saturation of Sphagnum, most likely resulted in a decrease of nitrogenase activity. Our results also showed that indirect $\mathrm{P}$ availability is able to modulate this response. However, the fact that nitrogenase activity was not stimulated by experimental $\mathrm{N}$ deprivation indicated that the impact of $\mathrm{N}$ deposition on Sphagnum-associated $\mathrm{N}_{2}$ fixation was much less apparent than assumed before, and far from understood. This study warranted further investigation of how Sphagnum-associated diazotrophs might control $\mathrm{N}_{2}$ fixation in relation to the environmental $\mathrm{N}$ availability and how this might be influenced by $\mathrm{P}$ availability. In addition, the 'memory effect' of the diazotrophic community associated with one Sphagnum species with respect to long-term $\mathrm{N}$ deposition, questioned the specificity of endo- and epiphytic diazotrophs for Sphagnum species and pointed at an important role of environmental parameters.

Acknowledgments We thank Daan Speth for helpful discussions. M.A.R.K. and C.L. were supported by ERC Ecomom 339880 to M.S.M.J., who was further supported by SIAM Gravitation grant 024002002 and the Spinoza award. K.F.E. was supported by Veni grant 863.13 .007 from NWO, C.F. was supported by the FP7 Grant 289300 EUROOT and an ERA-NET Plus Action Grant on Climate Smart Agriculture 'Cinderella' (FP 7 co-funded).

Open Access This article is distributed under the terms of the Creative Commons Attribution 4.0 International License (http:// creativecommons.org/licenses/by/4.0/), which permits unrestricted use, distribution, and reproduction in any medium, provided you give appropriate credit to the original author(s) and the source, provide a link to the Creative Commons license, and indicate if changes were made.

\section{References}

Andersen R, Chapman S, Artz R (2012) Microbial communities in natural and disturbed peatlands: a review. Soil Biol Biochem 57:979-994. doi:10.1016/j.soilbio.2012.10.003 
Berg A, Danielsson Å, Svensson BH (2012) Transfer of fixed-N from N2-fixing cyanobacteria associated with the moss Sphagnum riparium results in enhanced growth of the moss. Plant Soil 362:271-278. doi:10.1007/s11104-012-1278-4

Bobbink R, Hornung M, Roelofs JGM (1998) The effects of airborne nitrogen pollutants on species diversity in natural and semi-natural European vegetation. J Ecol 86:717-738. doi: 10.1046/j.1365-2745.1998.8650717.x

Bodelier PLE (2011) Toward understanding, managing, and protecting microbial ecosystems. Front Microbiol 2:80. doi: 10.3389/fmicb.2011.00080

Bragazza L (2006) A decade of plant species changes on a mire in the Italian Alps: vegetation-controlled or climate-driven mechanisms? Clim Chang 77:415-429. doi:10.1007/ s10584-005-9034-x

Bragazza L, Buttler A, Habermacher J, Brancaleoni L, Gerdol R, Fritze H, Hanajík P, Laiho R, Johnson D (2012) High nitrogen deposition alters the decomposition of bog plant litter and reduces carbon accumulation. Glob Chang Biol 18:11631172. doi:10.1111/j.1365-2486.2011.02585.x

Bragina A, Berg C, Cardinale M, Shcherbakov A, Chebotar V, Berg G (2011) Sphagnum mosses harbour highly specific bacterial diversity during their whole lifecycle. ISME J 6:112. doi:10.1038/ismej.2011.151

Bragina A, Oberauner-Wappis L, Zachow C, Halwachs B, Thallinger GG, Müller H, Berg G (2014) The Sphagnum microbiome supports bog ecosystem functioning under extreme conditions. Mol Ecol 23:4498-4510. doi:10.1111/mec. 12885

Canfield DE, Glazer AN, Falkowski PG (2010) The evolution and future of Earth's nitrogen cycle. Science 330:192-196. doi: 10.1126/science. 1186120

Capone DG (1993) Determination of nitrogenase activity in aquatic samples using the acetylene reduction procedure. In: Kemp PF, Sherr BF, Sherr EB, Cole JJ (eds) Handbook of methods in aquatic microbial ecology. Lewis Publishers, Boca Raton, pp 621-631

De Bont J, Mulder E (1976) Invalidity of the acetylene reduction assay in alkane-utilizing, nitrogen-fixing bacteria. Appl Environ Microbiol 31:640-647

Dixon R, Kahn D (2004) Genetic regulation of biological nitrogen fixation. Nat Rev Microbiol 2:621-631. doi:10.1038/ nrmicro954

Edgar RC (2010) Search and clustering orders of magnitude faster than BLAST. Bioinformatics 26:2460-2461. doi:10.1093/ bioinformatics/btq461

Edgar RC, Haas BJ, Clemente JC, Quince C, Knight R (2011) UCHIME improves sensitivity and speed of chimera detection. Bioinformatics 27:2194-2200. doi:10.1093/ bioinformatics/btr381

Fernández-Martínez M, Vicca S, Janssens IA, Sardans J, Luyssaert S, Campioli M, Chapin FS III, Ciais P, Malhi Y, Obersteiner M, Papale D, Piao SL, Reichstein M, Rodà F, Peñuelas J (2014) Nutrient availability as the key regulator of global forest carbon balance. Nat Clim Chang 4:471-476. doi:10. 1038/nclimate2177

Fowler D, Coyle M, Skiba U, Sutton MA, Cape JN, Reis S, Sheppard LJ, Jenkins A, Grizzetti B, Galloway JN, Vitousek P, Leach A, Bouwman AF, Butterbach-Bahl K, Dentener F, Stevenson D, Amann M, Voss M (2013) The global nitrogen cycle in the twenty-first century. Philos Trans
R Soc Lond B Biol Sci 368:20130164. doi:10.1098/rstb. 2013.0164

Fritz C, van Dijk G, Smolders AJP, Pancotto VA, Elzenga TJTM, Roelofs JGM, Grootjans AP (2012) Nutrient additions in pristine Patagonian Sphagnum bog vegetation: can phosphorus addition alleviate (the effects of) increased nitrogen loads. Plant Biol (Stuttg) 14:491-499. doi:10.1111/j.1438-8677. 2011.00527.x

Fritz C, Lamers LPM, Riaz M, van den Berg LJL, Elzenga TJTM (2014) Sphagnum mosses - masters of efficient N-uptake while avoiding intoxication. PLoS ONE 9:1-11. doi:10. 1371/journal.pone.0079991

Gaby JC, Buckley DH (2012) A comprehensive evaluation of PCR primers to amplify the nifH gene of nitrogenase. PLoS ONE 7:e42149. doi:10.1371/journal.pone.0042149

Gaby JC, Buckley DH (2014) A comprehensive aligned nifH gene database: a multipurpose tool for studies of nitrogen-fixing bacteria. Database (Oxford) 2014:bau001. doi:10.1093/ database/bau001

Gorham E (1991) Northern peatlands: role in the carbon cycle and probable responses to climatic warming. Ecol Appl 1:182195

Granath G, Limpens J, Posch M, Mücher S, de Vries W (2014) Spatio-temporal trends of nitrogen deposition and climate effects on Sphagnum productivity in European peatlands. Environ Pollut 187:73-80. doi:10.1016/j.envpol.2013.12. 023

Groen SC, Whiteman NK (2014) The evolution of ethylene signaling in plant chemical ecology. J Chem Ecol 40:700-716

Gruber N, Galloway JN (2008) An Earth-system perspective of the global nitrogen cycle. Nature 451:293-296. doi:10.1038/ nature 06592

Gunderson LH (2000) Ecological resilience - in theory and application. Annu Rev Ecol Syst 31:425-439

Ho A, Bodelier PLE (2015) Diazotrophic methanotrophs in peatlands: the missing link? Plant Soil. doi:10.1007/s11104015-2393-9

Khadem AF, Pol A, Jetten MSM, Op den Camp HJM (2010) Nitrogen fixation by the verrucomicrobial methanotroph "Methylacidiphilum fumariolicum" SolV. Microbiology 156:1052-1059

Kip N, Fritz C, Langelaan ES, Pan Y, Bodrossy L, Pancotto V, Jetten MSM, Smolders AJP, Op den Camp HJM (2011) Methanotrophic activity and diversity in different Sphagnum magellanicum dominated habitats in the southernmost peat bogs of Patagonia. Biogeosci Discuss 8:93579380

Knorr KH, Horn MA, Borken W (2014) Significant nonsymbiotic nitrogen fixation in Patagonian ombrotrophic bogs. Glob Chang Biol. doi:10.1111/gcb.12849

Laine J, Harju P, Timonen T, Laine AM, Tuittila E-S, Minkkinen K, Vasander H (2009) The intricate beauty of Sphagnum mosses - a Finnish guide to identification. University of Helsinki, Departmen of Forest Ecology Publications

Lamers L, Bobbink R, Roelofs J (2000) Natural nitrogen filter fails in polluted raised bogs. Glob Chang Biol 6:583-586

Lamers LPM, van Diggelen JMH, Op den Camp HJM, Visser EJW, Lucassen ECHET, Vile MA, Jetten MSM, Smolders AJP, Roelofs JGM (2012) Microbial transformations of nitrogen, sulfur, and iron dictate vegetation composition in 
wetlands: a review. Front Microbiol 3:156. doi:10.3389/ fmicb.2012.00156

Larmola T, Leppänen SM, Tuittila E-S, Aarva M, Merilä P, Fritze H, Tiirola M (2014) Methanotrophy induces nitrogen fixation during peatland development. Proc Natl Acad Sci U S A 111: 734-739. doi:10.1073/pnas.1314284111

Leppänen SM, Salemaa M, Smolander A, Mäkipää R, Tiirola M (2013) Nitrogen fixation and methanotrophy in forest mosses along a $\mathrm{N}$ deposition gradient. Environ Exp Bot 90:62-69. doi:10.1016/j.envexpbot.2012.12.006

Levy-Booth DJ, Prescott CE, Grayston SJ (2014) Microbial functional genes involved in nitrogen fixation, nitrification and denitrification in forest ecosystems. Soil Biol Biochem 75: 11-25. doi:10.1016/j.soilbio.2014.03.021

Limpens J, Berendse F, Klees H (2004) How phosphorus availability affects the impact of nitrogen deposition on sphagnum and vascular plants in bogs. Ecosystems 7:793-804. doi:10. 1007/s10021-004-0274-9

Ludwig W, Strunk O, Westram R, Richter L, Meier H, Yadhukumar, Buchner A, Lai T, Steppi S, Jobb G, Förster W, Brettske I, Gerber S, Ginhart AW, Gross O, Grumann S, Hermann S, Jost R, König A, Liss T, Lüssmann R, May M, Nonhoff B, Reichel B, Strehlow R, Stamatakis A, Stuckmann N, Vilbig A, Lenke M, Ludwig T, Bode A, Schleifer K-H (2004) ARB: a software environment for sequence data. Nucleic Acids Res 32:1363-1371. doi:10.1093/nar/gkh293

Novak M, Veselovsky F, Curik J, Stepanova M, Fottova D, Prechova E, Myska O (2015) Nitrogen input into Sphagnum bogs via horizontal deposition: an estimate for N-polluted high-elevation sites. Biogeochemistry. doi:10. 1007/s10533-015-0076-5

Opelt K, Berg C, Schönmann S, Eberl L, Berg G (2007) High specificity but contrasting biodiversity of Sphagnumassociated bacterial and plant communities in bog ecosystems independent of the geographical region. ISME J 1:502516. doi:10.1038/ismej.2007.58

Patberg W (2011) Solute transport in Sphagnum dominated bogs. Groningen

Postgate JR (1982) Biology nitrogen fixation: fundamentals. Philos Trans R Soc B Biol Sci 296:375-385

R Development Core Team (2012) R: a language and environment for statistical computing. R Foundation for Statistical Computing, Vienna, Austria

Raghoebarsing AA, Smolders AJP, Schmid MC, Rijpstra WIC, Wolters-Arts M, Derksen J, Jetten MSM, Schouten S, Sinninghe Damsté JS, Lamers LPM, Roelofs JGM, Op den Camp HJM, Strous M (2005) Methanotrophic symbionts provide carbon for photosynthesis in peat bogs. Nature 436: 1153-1156. doi:10.1038/nature03802

Rees DC, Tezcan FA, Haynes CA, Walton MY, Andrade S, Einsle O, Howard JB (2005) Structural basis of biological nitrogen fixation. Philos Trans A Math Phys Eng Sci 363:971-984. doi:10.1098/rsta.2004.1539, discussion 1035-40

Robertson GP, Vitousek PM (2009) Nitrogen in agriculture: balancing the cost of an essential resource. Annu Rev Environ Resour 34:97-125. doi:10.1146/annurev.environ. 032108.105046

Rousk K, Jones DL, Deluca TH (2013a) Moss-cyanobacteria associations as biogenic sources of nitrogen in boreal forest ecosystems. Front Microbiol 4:150. doi:10.3389/fmicb.2013.00150
Rousk K, Jones DL, DeLuca TH (2013b) Exposure to nitrogen does not eliminate N2 fixation in the feather moss Pleurozium schreberi (Brid.) Mitt. Plant Soil 374:513-521. doi:10.1007/s11104-013-1908-5

Schloss PD, Westcott SL, Ryabin T, Hall JR, Hartmann M, Hollister EB, Lesniewski RA, Oakley BB, Parks DH, Robinson CJ, Sahl JW, Stres B, Thallinger GG, Van Horn DJ, Weber CF (2009) Introducing mothur: open-source, platform-independent, community-supported software for describing and comparing microbial communities. Appl Environ Microbiol 75: 7537-7541. doi:10.1128/AEM.01541-09

Schwintzer CR (1983) Nonsymbiotic and symbiotic nitrogen fixation in a weakly minerotrophic peatland. Am J Bot 70: 1071-1078

Shaw AJ, Golinski GK, Clark EG, Shaw B, Stenøien HK, Flatberg $\mathrm{KI}$ (2014) Intercontinental genetic structure in the amphi-Pacific peatmoss Sphagnum miyabeanum (Bryophyta: Sphagnaceae). Biol J Linn Soc 111:17-37. doi:10.1111/bij.12200

Smith VH, Bennett SJ (1999) Nitrogen: phosphorus supply ratios and phytoplankton community structure in lakes: nutrient ratios. Arch Hydrobiol 146:37-53

Tomassen HBM, Smolders AJP, Limpens J, Lamers LPM, Roelofs JGM (2004) Expansion of invasive species on ombrotrophic bogs: desiccation or high $\mathrm{N}$ deposition? J Appl Ecol 41:139150. doi:10.1111/j.1365-2664.2004.00870.x

Ueda T, Suga Y, Yahiro N, Matsuguchi T (1995) Remarkable N2fixing bacterial diversity detected in rice roots by molecular evolutionary analysis of nifH gene sequences. J Bacteriol 177:1414-1417

Verhoeven JTA, Beltman B, Dorland E, Robat SA, Bobbink R (2011) Differential effects of ammonium and nitrate deposition on fen phanerogams and bryophytes. Appl Veg Sci 14: 149-157. doi:10.1111/j.1654-109X.2010.01113.x

Vile MA, Kelman Wieder R, Živković T, Scott KD, Vitt DH, Hartsock JA, Iosue CL, Quinn JC, Petix M, Fillingim HM, Popma JMA, Dynarski KA, Jackman TR, Albright CM, Wykoff DD (2014) N2-fixation by methanotrophs sustains carbon and nitrogen accumulation in pristine peatlands. Biogeochemistry 121:317-328. doi:10.1007/s10533-0140019-6

Vitousek P, Cassman K, Cleveland C (2002) Towards an ecological understanding of biological nitrogen fixation. Biogeochemistry 57(58):1-45

Weber A, Niemi M, Sundman V, Skujins J (1983) Acetylene reduction (N2 fixation) and endogenous ethylene releas in sub-boreal soils and peats of Finland. Oikos 41:219-226

Wu Y, Blodau C (2013) PEATBOG: a biogeochemical model for analyzing coupled carbon and nitrogen dynamics in northern peatlands. Geosci Model Dev 6:1173-1207. doi:10.5194/ gmd-6-1173-2013

Yoshinari T, Hynes R, Knowles R (1977) Acetylene inhibition of nitrous oxide reduction and measurement of denitrification and nitrogen fixation in soil. Soil Biol Biochem 9: 177-183

Zadorina EV, Slobodova NV, Boulygina ES, Kolganova TV, Kravchenko IK, Kuznetsov BB (2009) Analysis of the diversity of diazotrophic bacteria in peat soil by cloning of the nifH gene. Microbiology 78:218-226. doi:10.1134/ S0026261709020131

Zani S, Mellon MT, Collier JL, Zehr JP (2000) Expression of nifH genes in natural microbial assemblages in Lake George, New 
York, detected by reverse transcriptase PCR. Appl Environ Microbiol 66:3119-3124. doi:10.1128/AEM.66.7.31193124.2000

Zehr JP, McReynolds L (1989) Use of degenerate oligonucleotides for amplification of the nifH gene from the marine cyanobacterium Trichodesmium thiebautii. Appl Environ Microbiol 55:2522-2526

Zehr JP, Jenkins BD, Short SM, Steward GF (2003) Nitrogenase gene diversity and microbial community structure: a crosssystem comparison. Environ Microbiol 5:539-554 